\title{
U.S. Geological Survey Programs in Georgia
}

\section{U.S. Department of the Interior - U.S. Geological Survey}

Georgia has a rich natural endowment in its land, water, biological, and mineral resources. The material needs of society are ultimately met by these resources. The U.S. Geological Survey (USGS) provides unbiased earth-science information and research that are vital for society to use wisely, care for, and live safely within our natural environment. This Fact Sheet describes a few of the many USGS activities in Georgia.

USGS work in Georgia is pursued in partnership with many local, State, and other Federal agencies. Examples of these partners are the city of Brunswick; the Albany Water, Gas, and Light Commission; Gwinnett County; the Georgia Environmental Protection Division; the U.S. Army Corps of Engineers; the U.S. Department of Energy; and the University System of Georgia.

\section{Supply and Use of Earth Resources}

Georgia has an abundant supply of freshwater, which includes an extensive system of rivers, several productive aquifers, and average annual precipitation of 50 inches (figs. 1, 2). However, population growth and economic development have led to competing demands for water resources in some areas. In addition, surface-water supplies can become critically low during periods of drought, such as those Georgia experienced from 1980 to 1982 and from 1985 to 1989 , when streamflows in northern Georgia were at or near the lowest of this century. The USGS responded by making hundreds of nonroutine, low-flow discharge measurements and documented the droughts with special reports. Drought investigations supplement streamflow records routinely collected by the USGS in Georgia since the early 1890's and provide the fundamental basis for predictions of low-flow discharges. conditions.
Ground-water supplies have become limited in some areas where demand exceeds natural recharge rates. Since pumping began in the late 1800's, the ground-water level in the Floridan aquifer system at Brunswick has declined as much as 65 feet. This water-level decline has allowed saline water to migrate upward in some areas of the aquifer system. The USGS monitors ground-water levels and quality in Georgia, and studies are underway in several aquifers to predict water levels and potential contamination under various climatic and water-withdrawal

Basic water-resources data collected by the USGS provide information that is essential to water-resources management. The USGS operates and collects data at 134 continuous-record and 102 partialrecord streamflow-gaging stations, 18 reservoir stage and contents gaging stations, about 170 continuous-record observation wells, and numerous miscellaneous sites. These data provide information that is used daily by managers to make decisions that

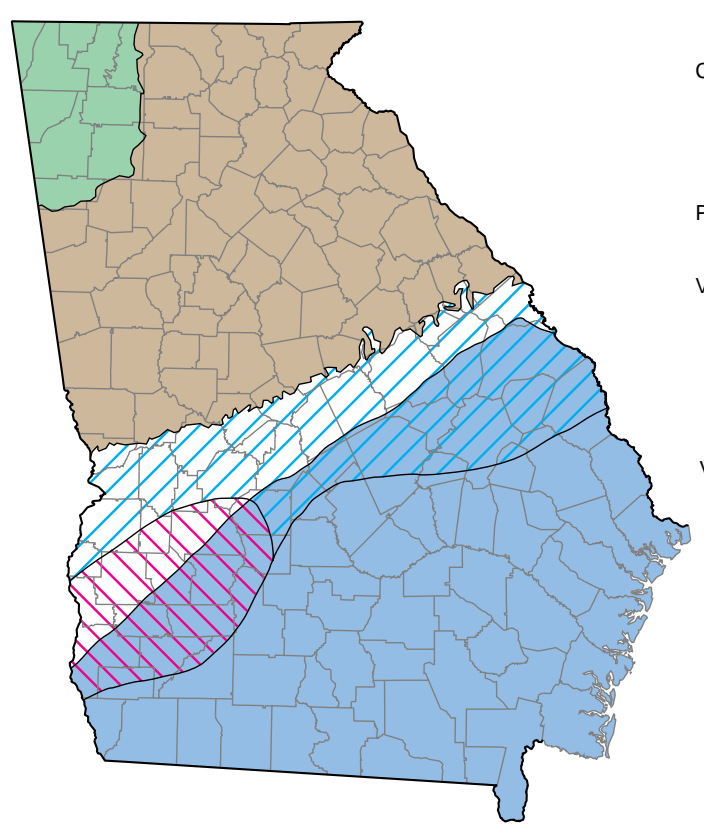

EXPLANATION

COASTAL PLAIN AQUIFERS

$\square$ Floridan aquifer system

$\triangle \nabla$ Claiborne, Clayton, and Providence aquifers

$\square \triangle$ Cretaceous aquifer systems

PIEDMONT AND BLUE RIDGE AQUIFERS

$\square$ Crystalline-rock aquifers

VALLEY AND RIDGE AND APPALACHIAN PLATEAUS AQUIFERS

$\square$ Paleozoic rock aquifer

$\square$ Not a principal aquifer
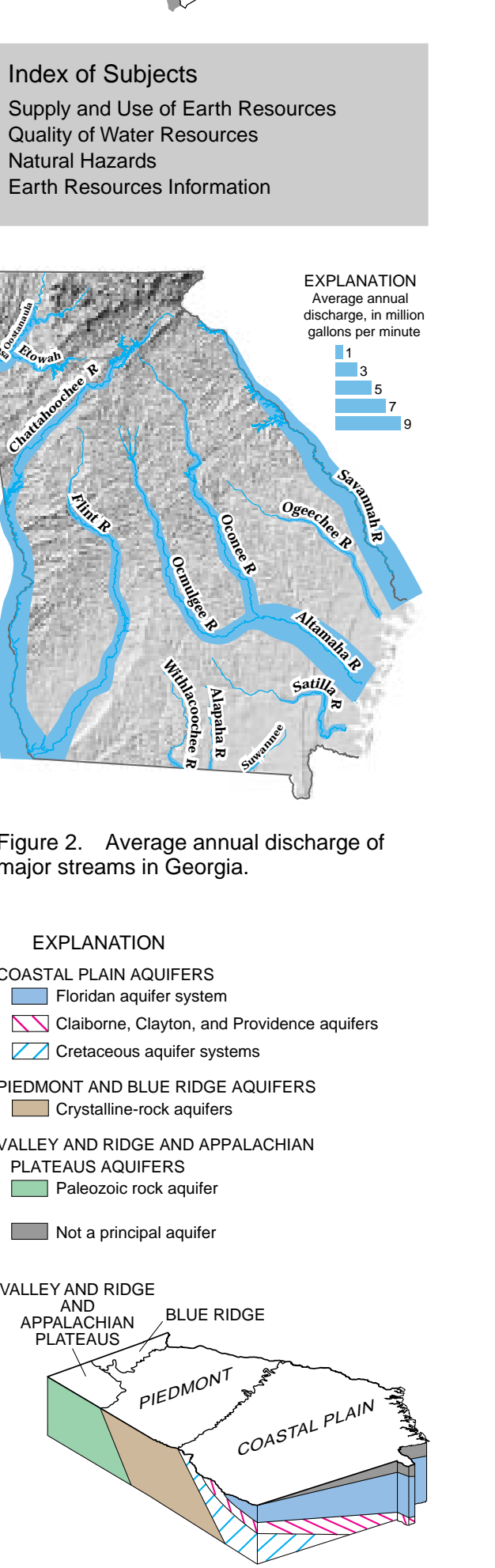

Figure 1. Area of use of principal aquifers and generalized diagram showing aquifers and physiographic provinces in Georgia. 
concern water supply, flood control, hydroelectric power, irrigation, bridge design, wildlife management, and pollution abatement. Water-resource management also requires information on the use of water for public supplies, irrigation, industry, and power generation. Water use during 1990, excluding use for thermoelectric power generation, was 2,290 million gallons per day (fig. 3).

\section{Water Limitations in the Apalachicola-Chattahoochee-Flint River Basin}

During the period from 1970 to 1990 , water used for public supply in the Apalachicola-Chattahoochee-Flint River Basin, which includes the Metropolitan Atlanta area, more than tripled to almost 460 million gallons per day. Severe droughts and increased development in the area have resulted in shortages and restrictions on limited surface-water supplies. In northern Georgia, ground water has not been a major source of supply because of its sporadic occurrence in the crystalline rocks of the Piedmont Physiographic Province (fig. 1). The USGS is using state-ofthe-science geologic and geophysical techniques to address the feasibility of using ground water as a supplemental source of supply in this region. The USGS also is evaluating how changes in surface- and ground-water withdrawals affect regional water availability, and areas where groundwater resources are overused or underused. Preliminary results for the lower part of

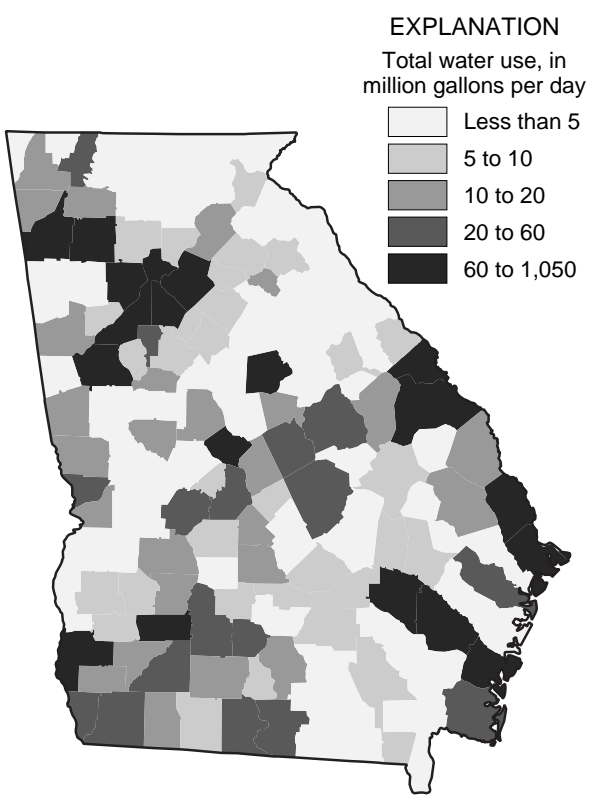

Figure 3. Water use in Georgia, by county, 1990. the Basin indicate that pumping increases in the Basin could cause a reduction in ground-water discharge to streams and result in reduced flow to Apalachicola Bay, especially during droughts.

\section{Geology and Geohydrology of Northern Georgia}

USGS geologists are providing a base of modern geologic mapping for areas of the Piedmont and Blue Ridge Physiographic Provinces (fig. 1), as part of the Georgia Appalachians Project. An inventory of the location and size of deposits of mineral resources also is being developed. The inventory includes industrial minerals, such as carbonate rock for paper whitener; industrial chemicals, such as ocher for pigmentation; and many other rock products that are widely used for construction of buildings and roads in Georgia.

The USGS is developing tools to evaluate the availability of ground-water resources and the potential transport of ground-water contaminants. USGS geologists and hydrologists are mapping subsurface fracture systems to investigate ground-water flow in the Piedmont of Georgia and to determine the effects of these fracture systems on well yield. USGS scientists also are working northwest of Atlanta to investigate the processes that control the extent and movement of ground water contaminated with chlorinated solvents, which may endanger local ground-water resources.

\section{Quality of Water Resources}

The quality of water is vital to support society's needs and to sustain rich and diverse ecosystems in Georgia. The USGS is studying the effects of land use on the physical, chemical, and biological quality of water. Recent studies have focused on water-quality effects of point- and nonpointsources of pollutants from urban watersheds, and nonpoint-sources from agricultural and forested (managed for silviculture) watersheds (fig. 6, on back page).

\section{Phosphorus in the Upper Chattahoochee River}

During the period from 1980 to 1993 , Metropolitan Atlanta's population increased by about 43 percent, thus resulting in an increase of about 50 percent in wastewater discharge to the Chattahoochee River from the six largest Atlanta wastewater-treatment facilities. Treated wastewater is a point source of the nutrient phosphorus. Increased phosphorus loadings can produce rapidly multiplying algal blooms that degrade the recreational, water-supply, and habitat value of streams and lakes. The amounts (loads) of phosphorus discharged to the Chattahoochee River increased before 1989 and then decreased following legislated restrictions on the use of phosphate detergents combined with upgrades to wastewater-treatment facilities. Even though the volume of effluent increased from 1988 to 1993, phosphorus loads from wastewater-treatment facilities decreased by about 83 percent because of reduced phosphorus concentrations in raw sewage and improved treatment methods.

The annual phosphorus load at monitoring sites on the Chattahoochee River upstream and downstream from Atlanta from 1980 to 1993 is shown in figure 4. The difference between the two curves shown on the graph indicates the effect of point and nonpoint sources from Atlanta on the phosphorus load in the River. Reductions in pointsource phosphorus loads have been documented, and phosphorus loads in the river downstream from Atlanta declined by about 54 percent from 1988 to 1993 . However, phosphorus loads discharged to the Chattahoochee River from Atlanta wastewatertreatment facilities in 1996 remained higher than legislated maximum levels.

\section{Pesticides From Urban and Agricultural Sources}

Agricultural land uses (fig. 6, on back page) often are assumed to be the primary source of pesticides in the environment. Water samples collected weekly from March 1993 through April 1994 from streams that drain urban and agricultural watersheds were analyzed for many commonly used pesticides. Twenty-four herbicides and eight insecticides were detected in water samples. Preliminary findings

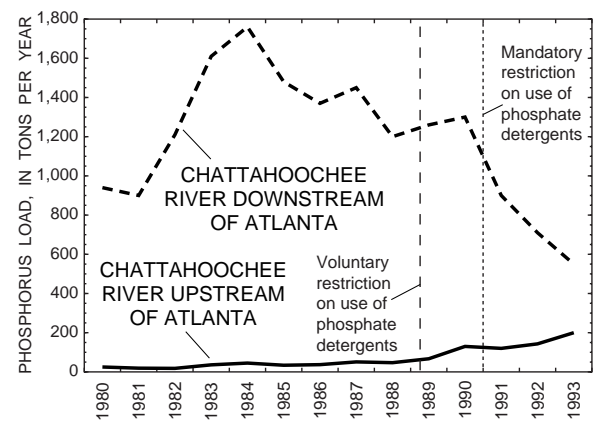

Figure 4. Phosphorus loads in the Chattahoochee River upstream and downstream from Atlanta, 1980 to 1993. 
indicate that more pesticides are present in water from urban watersheds, generally at higher concentrations and for a greater part of the year, than in water from agricultural watersheds. In general, the trace concentrations of pesticides detected do not exceed U.S. Environmental Protection Agency (USEPA) drinking-water standards for human health. However, concentrations of several insecticides detected in urban watersheds exceed guidelines for the protection of aquatic life.

\section{Fish Communities in Urban Streams}

Because aquatic organisms respond directly to the quality of the water they inhabit, they are useful indicators of the cumulative effects of water quality. The USGS surveyed fish communities in Chattahoochee River tributaries and compared streams that receive runoff from the Metropolitan Atlanta area with a stream in a forested basin. In general, the urban basins had fewer than one-half the number of fish in the forested basins, and about 90 percent of the fish in urban basin were nonnative species. Fish that live in urban streams generally are tolerant of a wide range of water-quality conditions, and after such mishaps as chemical or sewage spills that decrease fish populations, these fish types are opportunistic and can repopulate urban streams rapidly.

\section{Water Quality During Tropical Storm Alberto}

Tropical Storm Alberto in 1994 caused record flooding. In Georgia, the flood provided a unique opportunity to measure the nutrients, suspended sediments, and pesticides transported during extreme floods.

Twenty pesticides commonly used in agricultural and urban areas were detected in floodwaters. Pesticide concentrations were well below USEPA standards for drinking water. However, concentrations of the insecticides chlorpyrifos, carbaryl, and diazinon approached or exceeded USEPA guidelines for protection of aquatic life. Pollutants flushed from the land surface during storm runoff tended to reach streams during the first portion of a flood. The highest herbicide concentrations were measured 4 to 6 days before the flood peak in the Flint River at Newton (fig. 5). Concentrations decreased as flooding progressed because of the combined effects of dilution and the passing of the "first flush" pollutants. This information can be used to evaluate potential pollution characteristics of future extreme floods.

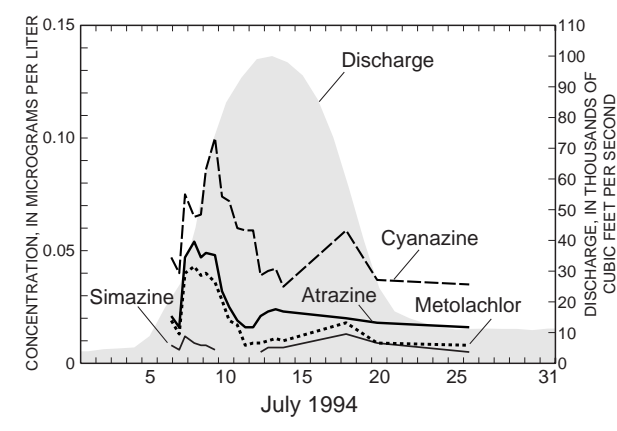

Figure 5. Herbicide concentrations and discharge in the Flint River at Newton.

\section{Water Quality in a Major Aquifer}

The Floridan aquifer system is one of the most productive in the United States and is the source of water supply for the city of Valdosta and much of the surrounding area in southeastern Georgia. Water quality in the Upper Floridan aquifer is affected by direct recharge from Withlacoochee River water (fig. 2) through sinkholes in and near the streambed north of Valdosta. The river water contains naturally occurring organic matter and receives little filtration as it recharges the aquifer, which results in high concentrations of organic carbon, hydrogen sulfide, and methane in ground water downgradient from the recharge area. The USGS measured and characterized water quality in the Upper Floridan aquifer. Concentrations of naturally occurring constituents in ground water from several locations were used to trace the movement of recharge water in the Upper Floridan aquifer. Findings from this investigation were used by water-resource managers and planners to assess the contamination potential of the aquifer by recharge from the Withlacoochee River and to delineate areas suitable for new public water-supply wells.

\section{Natural Hazards}

Natural hazards cause losses that average about $\$ 52$ billion per year in the United States. In Georgia, the USGS provides information on natural hazards, which include floods, droughts, earthquakes, sinkholes, and coastal storm surges.

\section{Flood Hazards}

In July 1994, parts of central and southwestern Georgia in the Flint and the Ocmulgee River Basins were inundated by floods that resulted from as much as 28 inches of rainfall produced by Tropical Storm Alberto. The floods caused 33 deaths and property damage estimated to be nearly $\$ 1$ billion as highways, water systems, crops, and homes were inundated. Damage from such a severe flood cannot be averted completely, but with reliable estimates of river stages and discharge, communities can be warned of impending danger. The USGS operates data transmitters at 56 of its continuous stage-monitoring stations Statewide. Fifteen of these stations in the affected basins provided near-realtime tracking of flood conditions during Tropical Storm Alberto. Personnel of the USGS worked throughout the flood to maintain stream gages, to measure peak-flow rates and flood-elevation profiles, and to provide critical information to emergency management personnel and the public.

\section{Geologic Hazards}

Earthquakes and ground failures are uncommon events in Georgia; however, they can pose a threat to human life and property. Although Georgia has experienced only small to moderate earthquakes in recorded history, nearby States experienced large seismic events during the 1800's. Shock waves from earthquakes anywhere in the Southeastern United States can affect Georgia. The USGS National Earthquake Information Center World Wide Web (WWW) site

\section{http://wwwneic.cr.usgs.gov/} documents earthquakes through the U.S. National Seismograph Network with such stations as the one near Eatonton. In addition, the USGS investigates the causes of earthquakes and delineates possible earthquake faults. Ground failures, such as landslides, are a common byproduct of seismic shaking and also can be caused by unstable surface conditions. The USGS has supported projects to identify areas of potential ground failure to ensure the stability of large structures such as dams.

\section{Earth-Resources Information}

\section{Hydrologic and Geologic Information}

The USGS provides hydrologic information on stream stage and discharge, water quality, and ground-water levels. The USGS also provides interpretative information about water and geologic earth resources to describe the availability, use, quality, prospective and retrospective trends, and potential impacts from various factors such as land use. Investigative techniques and computer models developed by the USGS are used daily by resource managers, engineers, hydrologists, geologists, educators, and others who serve the citizens of Georgia. 


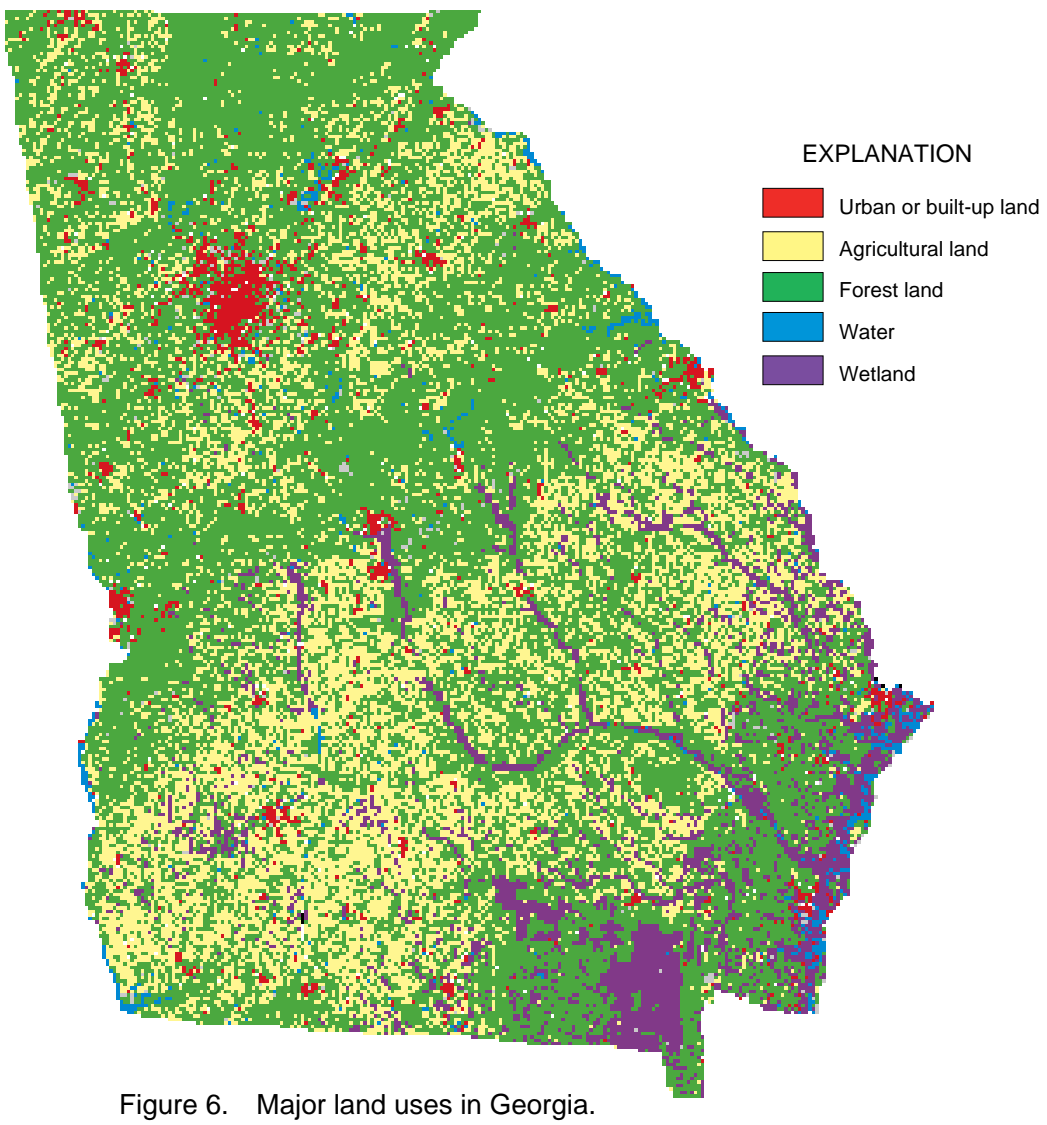

Information is available in annual data reports, special investigative reports, fact sheets, and on the USGS WWW site for Georgia

\section{http://wwwga.usgs.gov/}

which describes hydrologic conditions, current investigations, and the availability of other information products.

\section{Biological Resources Information}

The USGS Biological Resources Division (formerly the National Biological Service) provides information to improve the understanding of priority species, fisheries, songbirds, and forests in Georgia. At the request of Federal and State agencies, scientists conduct investigations of forest and aquatic habitats and species in Georgia. For example, scientists are studying the effects of pine timberland management on habitats required by migratory birds and woodpeckers. The USGS has provided essential information for management of important game fish such as the striped bass. Other investigations are assessing the effects of streamflow regulation on the spawning and foraging habitats necessary to sustain diverse fish populations.

\section{Mapping the Earth}

Among the most popular and versatile products of the USGS are its 1:24,000-scale topographic maps - 1 inch represents 2,000 feet on the ground. These maps show basic natural and cultural features of the landscape, such as mountains and valleys, lakes and streams, towns, and highways; contour lines on these maps show the elevation and shape of terrain. Georgia is covered by 1,017 topographic maps at this scale. These maps are used for civil engineering, naturalresource monitoring, hiking, camping, exploring, and many other purposes.

The USGS also provides extensive digital-mapping data that are widely used in geographic information system (GIS) data bases. The USGS National Geospatial Data Clearinghouse WWW site http://nsdi.usgs.gov/nsdi/ contains additional information on these digital-mapping products. The USGS Earth Resources Observation Systems Data Center near Sioux Falls, South Dakota, WWW site

\section{http://edcwww.cr.usgs.gov/}

distributes a variety of aerial photographs and satellite-image data products that cover the entire State. The Center for Spatial Analysis Technology, which is a joint research effort of the USGS, the Georgia Environmental Protection Division, and the Georgia Institute of Technology, performs GIS analysis and research.
USGS State representative 3039 Amwiler Road, Suite 130 Atlanta, GA 30360-2824

(770) $903-9100$

Fax: (770) 903-9199

Email: info@wwwga.usgs.gov HomePage: http://wwwga.usgs.gov

Additional earth science information can be found by accessing the USGS Home Page on the World Wide Web at http://www.usgs.gov/

For more information on all USGS reports and products (including maps, images, and computerized data), call 1-800-USA-MAPS

The USGS provides maps, reports, and information to help others meet their needs to manage, develop, and protect America's water, energy, mineral, biological, and land resources. We help find the natural resources needed to build tomorrow, and supply the scientific understanding needed to help minimize or mitigate the effects of natural hazards and environmental damage caused by natural and human activities. The results of our efforts touch the daily life of almost every American. Fact Sheet FS-010-96 